UNDERGRADUATE RESEARCH IN NATURAL AND CLINICAL SCIENCE AND TECHNOLOGY (URNCST) JOURNAL

Read more URNCST Journal articles and submit your own today at: https://www.urncst.com

\title{
Introducing a Novel Undergraduate Research Education Initiative: The URNCST Journal Mentored Paper
}

Ayomide Fakuade, BSc [1], Stephanie Nagy, BScN Student [1], Neethu Pavithran, BSc Student [1], Saameh Siddique, BASc Student [1], Jeremy Y. Ng, MSc, PhD Candidate [1]*

[1] URNCST Journal, Toronto, Ontario, Canada

*Corresponding Author: editor@urncst.com

\begin{abstract}
The Undergraduate Research in Natural and Clinical Science and Technology (URNCST) Journal Mentored Paper initiative is a unique undergraduate research education opportunity open to undergraduate and professional-undergraduate degree students internationally. Participants are invited to submit an abstract on a selected topic and be paired with a graduate student mentor with an interest and expertise in the research area. Over a three-month period, the mentor and mentee(s) work together to turn the unpolished abstract into a full-length manuscript of publishable quality. In this short editorial, we provide an overview of how our editorial team successfully conceptualized, developed, and established this initiative. Undergraduate students interested in submitting an abstract to the next URNCST Journal Mentored Paper round should visit: https://www.urncst.com/index.php/urncst/mentored_paper. Graduate students interested in serving as a mentor should visit https://www.urncst.com/index.php/urncst/about/\# Toc487899585 to apply to the URNCST Journal.
\end{abstract}

Keywords: mentored paper; research education; undergraduate journal; undergraduate research; URNCST Journal

\section{Introduction}

The Undergraduate Research in Natural and Clinical Science and Technology (URNCST) Journal Mentored Paper initiative was developed to provide undergraduate (i.e. BSc, BEng, BA) and professional-undergraduate (i.e. MD, DDS, PharmD, OD, RN) degree students with the opportunity to investigate a topic of interest to them, receive mentorship from a graduate-level student with an interest and expertise in the field in writing a research protocol or review, submit a manuscript to the URNCST Journal, receive and address peer-reviewed feedback, with the eventual aim of publishing a full-length article in the URNCST Journal. This initiative was born out of a number of observations made by our editorial board since the journal's inception in 2017: 1) that undergraduate students are often highly keen to participate in research endeavours that recognize their academic talents, and 2) that this energy often remains unharnessed, as these undergraduate students face a number of challenges in finding the necessary guidance and high-quality opportunities which allow them to hone their academic writing and critical thinking skills in research. In our experience, we have found that despite the existence of a plethora of undergraduate research journals, these publications are largely operated by undergraduate students themselves who may lack the necessary skillsets and competencies needed for the provision of meaningful mentorship. On the other hand, many graduate students work in isolation and may lack the ability to engage in mentoring an undergraduate student, despite possessing all the necessary skillsets to do so. Yet, another problematic issue includes the fact that even across undergraduate students that do find success in landing a research position, the vast majority are thrust into the midst of an ongoing project and are typically asked to contribute to a portion of the study's data collection or analysis. Thus, even the most experienced undergraduate researchers typically make the decision to attend graduate school with little knowledge or experience in conceptualizing a research study, selecting a suitable methodology, writing a manuscript, and addressing/receiving peer-reviewed feedback. This delayed disconnect in training, which separates data collection/analysis and all other steps, often provides students with an unclear picture of what a career in academic research truly looks like. This, in turn, results in two problems: 1) that by the time undergraduate students become graduate trainees they realize too late that they do not want a career in undergraduate research, and 2) that by failing to be provided with the opportunity to see the "big picture" many undergraduate students elect not to attend graduate school mistakenly believing that they will only continue to collect/analyze data, thus potentially missing a career opportunity that suits their untapped interests and strengths. The recognition of these aforementioned knowledge gaps that exist in between the academic training trajectory of a student, as they transition from undergraduate to graduate training, serves as the basis for why the mentored paper initiative was born. 
UNDERGRADUATE RESEARCH IN NATURAL AND CLINICAL SCIENCE AND TECHNOLOGY (URNCST) JOURNAL Read more URNCST Journal articles and submit your own today at: https://www.urncst.com

\section{Eligibility and Application Process}

Any undergraduate or professional-undergraduate students are eligible to participate in the URNCST Journal Mentored Paper initiative, which is scheduled to occur in three rounds (4 months per round) annually. At the beginning of each competition round, a call is made by the URNCST Journal to submit an abstract in the format of either a study protocol or a review. The abstract must focus on a topic from a selected list of research topics which change every round. Prior to the start of each round, graduate students are invited to provide topics, in the form of a research question, relating to their area(s) of interest and expertise, with the intention of serving as the mentor to participants submitting abstracts corresponding with their topic(s). Once all the topics are finalized, they are publicly listed on the journal's website. Undergraduate students are then invited to write an abstract of a research proposal relating to one of these topics and submit it for consideration in groups of up to 3 authors. These abstracts are then evaluated by the respective graduate student mentors, and assigned a score based on the quality and content of their abstract. Therefore, in order to be successful, applicants must demonstrate a base-level of academic writing ability and show preparedness with respect to their chosen topic by reviewing the appropriate peer-reviewed literature. Successful applicants are then paired with the respective graduate student mentor who proposed their abstract's topic, and are expected to commit to a three-month mentorship period to refine the research question and methodology under the supervision of their mentor with the goal of writing a full-length study protocol or review. At the end of the three-month period, participants submit their final manuscript to the URNCST Journal, after which point it is evaluated for quality internally by the editor or an associate editor. If the manuscript is found to be of satisfactory quality at facevalue, it is sent out for peer-review, otherwise it is returned to the mentee(s) and mentor for further polishing. Once peer-reviewed feedback is received, this is shared with the authors who may work with their mentor to address the reviewers' suggestions satisfactorily, before a revised version is re-submitted to the journal. At this point, the editor or an associate editor renders an editorial decision on the manuscript, moving to either accept, request further revisions or decline resubmitted articles for publication. Given that this is designed to be a learning experience for participants, whereby undergraduate students are provided with a unique research education, every effort is made to encourage and guide participants to the point whereby their articles are deemed suitable for publication in the URNCST Journal, even if this requires multiple revision rounds on the part of the authors. By participating in this opportunity, undergraduate students engage in the process of learning how to conceptualize and design a research study on a given topic of interest, select and apply the appropriate research methodology based on the nature of their study design, collect and report their (anticipated, if a protocol) results, and discuss the impacts and implications of their (anticipated) findings. Further to this, participants are able to deepen their research interests as they are provided with the unique opportunity to write a full-length manuscript under the guidance of a graduate student with expertise in their chosen topic area, and receive and address peerreviewed feedback, often for the first time in their career.

\section{Promoting the Initiative: The Role of Engagement Officers}

One key aspect of the URNCST Journal Mentored Paper itself involves ensuring that prospective students who wish to participate in the initiative are aware of the opportunity to submit an abstract. Engagement officers (EOs) play crucial roles in the day-to-day operations of the URNCST Journal, however, they play a special role in promoting the initiative once a call for abstracts is announced. Their responsibilities evolve depending on the stage of the round. During the initial abstract submission phase, EOs are tasked with the promotion and marketing activities on various social media platforms and student organizations with an interest in undergraduate research. During the later phases of the competition, EOs assist with identifying new graduate mentors for future rounds, new organizations with an interest in sharing the initiative with their general members, and providing critical feedback on improving the experience for current round participants.

\section{Standardizing Promotion and Managing Abstract Submissions: The Role of Engagement Leads}

The URNCST Journal retains a team of 15-20 EOs at any given time throughout the year. Supervision of EOs are overseen by a team of 3-5 engagement leads (ELs) who report directly to the managing editor of the URNCST Journal Mentored Paper round. ELs are comprised of former EOs who have demonstrated a high level of responsibility, dedication and organization to advancing the URNCST Journal's mission. Throughout the entire duration of the mentored paper initiative, the ELs meet weekly with the managing editor to identify and delegate tasks, troubleshoot issues, agree on assigned deadlines, and discuss the progress of previously assigned and ongoing tasks within the journal. They are responsible for assigning weekly tasks to each EO, tracking their progress, and holding them accountable for completing their tasks. ELs are concurrently responsible for tracking social media activity, ensuring that EOs do not "double-promote" the mentored paper initiative, promotional messages are written in a standardized, professional and respectful fashion, and prospective applicants' inquiries are responded to promptly and respectfully, thereby preventing spamming practices. Once the call for abstract submissions closes, ELs sort abstracts by topic, record all pertinent details in a shared spreadsheet, and perform preliminary checks for completion, prior to them being sent to the graduate student mentors for evaluation. 
UNDERGRADUATE RESEARCH IN NATURAL AND CLINICAL SCIENCE AND TECHNOLOGY (URNCST) JOURNAL Read more URNCST Journal articles and submit your own today at: https://www.urncst.com

Developing Schedules for Mentees and Mentors: Routine Check-ins \& "Block" Mentorship Design

The development of the URNCST Journal Mentored Paper initiative consisting of three rounds (4 months per round) required a significant amount of planning and consideration. A schedule outlining a timeline of tasks from beginning to end was designed in such a way that it provides mentees and mentors with an adequate amount of time to complete a series of tasks that allowed participants to turn an unpolished abstract into a publishable full-length manuscript, but that also holds them accountable to deadlines to ensure that bi-weekly milestones are met. To achieve this, we developed a block mentorship design, whereby the three-month mentorship period is broken up into 6 blocks (two-week intervals per block). In the month ahead of the three-month mentorship period, mentors are provided with a schedule which details a breakdown of the blocks and the respective deliverables that mentees will be expected to complete at the end of each two-week period. At the beginning of the first block, a representative from the journal makes introductions between the mentor and mentee(s) via email and asks that both meet to introduce themselves, but also decide on how often they will meet over the next three months. While some blocks require more work than others, they were purposefully designed with a student (who is concurrently pursuing a full-time undergraduate degree) in mind. A benefit of the block mentorship design was the flexibility with which participants were made aware of at the very beginning of the round; in other words, they may work towards the completion of their tasks during any time across these 14 days. Thus, participants can plan accordingly to complete their tasks around their other competing responsibilities, with the awareness that the deadline of new deliverables every two weeks eliminates the chance for them to complete all tasks in a rushed fashion at the last minute. At the beginning of blocks two to six, mentors also receive a check-in email from a journal representative, inquiring about their progress with their mentee(s). This check-in system served as an added mechanism to ensure accountability with respect to task completion, both on the parts of mentors and mentees. A breakdown of the 6 blocks and their respective deliverables (both mentor and mentee(s)) are provided in Table 1 .

Table 1. URNCST Journal Mentored Paper Schedule

\begin{tabular}{|c|c|}
\hline Block & Deliverables \\
\hline $\begin{array}{l}\text { Block } 1 \\
(\text { Weeks 1-2) }\end{array}$ & $\begin{array}{l}\text { 1. Hold introductory meeting (mentor and mentee) } \\
\text { 2. Provide mentee with feedback on their originally submitted abstract (mentor) } \\
\text { 3. Discuss expectations/meeting schedule (mentor and mentee) } \\
\text { 4. Define the exact research question (mentor and mentee) } \\
\text { 5. Draft rough dot jot outline that describes the direction of the paper including a short list of } \\
\text { literature that could be cited in the final paper (mentor and mentee) }\end{array}$ \\
\hline $\begin{array}{l}\text { Block } 2 \\
\text { (Weeks 3-4) }\end{array}$ & $\begin{array}{l}\text { 1. Conduct literature search to identify relevant literature surrounding research question topic area } \\
\text { (mentee with guidance from mentor) } \\
\text { 2. Compile list of potential references to cite in the final paper, begin writing the Introduction \& } \\
\text { Methods section (mentee) }\end{array}$ \\
\hline $\begin{array}{l}\text { Block } 3 \\
(\text { Weeks 5-6) }\end{array}$ & $\begin{array}{l}\text { 1. Provide feedback on literature search/reference list (mentor) } \\
\text { 2. Finish writing Introduction \& Methods sections of the manuscript (mentee and mentor) }\end{array}$ \\
\hline $\begin{array}{l}\text { Block } 4 \\
\text { (Weeks 7-8) }\end{array}$ & $\begin{array}{l}\text { 1. Provide feedback on Introduction \& Methods sections of the manuscript (mentor) } \\
\text { 2. Begin writing Results and Discussion sections of the manuscript (mentee) }\end{array}$ \\
\hline $\begin{array}{l}\text { Block } 5 \\
(\text { Weeks 9-10) }\end{array}$ & $\begin{array}{l}\text { 1. Finish writing the Results \& Discussion sections of the manuscript (mentee) } \\
\text { 2. Provide feedback on Results \& Discussion sections of the manuscript (mentor) }\end{array}$ \\
\hline $\begin{array}{l}\text { Block } 6 \\
(\text { Weeks 11-12) }\end{array}$ & $\begin{array}{l}\text { 1. Complete all final revisions/edits of the manuscript (mentee) } \\
\text { 2. Format manuscript accordingly to URNCST Journal submission guidelines (mentee) } \\
\text { 3. Review over formatted manuscript (mentor) } \\
\text { 4. Submit manuscript (mentee) }\end{array}$ \\
\hline
\end{tabular}

\section{Conclusion}

In line with the URNCST Journal's mission to support undergraduate research endeavours worldwide, we believe that the URNCST Journal Mentored Paper initiative helps achieve this in both a novel and an innovative way. We believe that this initiative addresses an important knowledge gap that lies between undergraduate and graduate-level research training, and this opportunity will positively impact participants' research education, but also provide them with the ability to make a more informed 
decision as to whether to pursue future graduate-level research training. It should also be mentioned that this initiative also provides graduate student mentors with the invaluable experience of engaging in undergraduate mentorship to hone their supervisory skills, an activity that is expected of graduate trainees who seek faculty positions post-graduation at an academic institution.

\section{List of Abbreviations Used}

EO: engagement officer

EL: engagement lead

\section{Conflicts of Interest}

The authors declare that they have no conflict of interests.

\section{Authors' Contributions}

AF: is currently a Deputy Editor for the URNCST Journal, co-drafted the manuscript, and gave final approval of the version to be published.
SN: is currently an Engagement Lead for the URNCST Journal, co-drafted the manuscript, and gave final approval of the version to be published.

NP: is currently an Engagement Lead for the URNCST Journal, co-drafted the manuscript, and gave final approval of the version to be published.

SS: is currently an Engagement Lead for the URNCST Journal, co-drafted the manuscript, and gave final approval of the version to be published.

JYN: is the founding Editor-in-Chief of the URNCST Journal, critically revised the manuscript, and gave final approval of the version to be published.

\section{Acknowledgements}

We gratefully acknowledge all engagement officers, graduate student mentors, and peer-reviewers who have generously contributed their time and efforts to the publication, without whom the URNCST Journal Mentorship Initiative would not be possible.

\section{Article Information}

Managing Editor: Jeremy Y. Ng

Article Dates: Published Dec 2820

\section{Citation}

Please cite this article as follows:

Fakuade A, Nagy S, Pavithran N, Siddique S, Ng JY. Introducing a novel undergraduate research education initiative: The URNCST Journal Mentored Paper. URNCST Journal. 2020 Dec 28: 4(11).

https://urncst.com/index.php/urncst/article/view/232

DOI Link: https://doi.org/10.26685/urncst.232

\section{Copyright}

(C) Ayomide Fakuade, Stephanie Nagy, Neethu Pavithran, Saameh Siddique, Jeremy Y. Ng. (2020). Published first in the Undergraduate Research in Natural and Clinical Science and Technology (URNCST) Journal. This is an open access article distributed under the terms of the Creative Commons Attribution License (https://creativecommons.org/licenses/by/4.0/), which permits unrestricted use, distribution, and reproduction in any medium, provided the original work, first published in the Undergraduate Research in Natural and Clinical Science and Technology (URNCST) Journal, is properly cited. The complete bibliographic information, a link to the original publication on http://www.urncst.com, as well as this copyright and license information must be included.
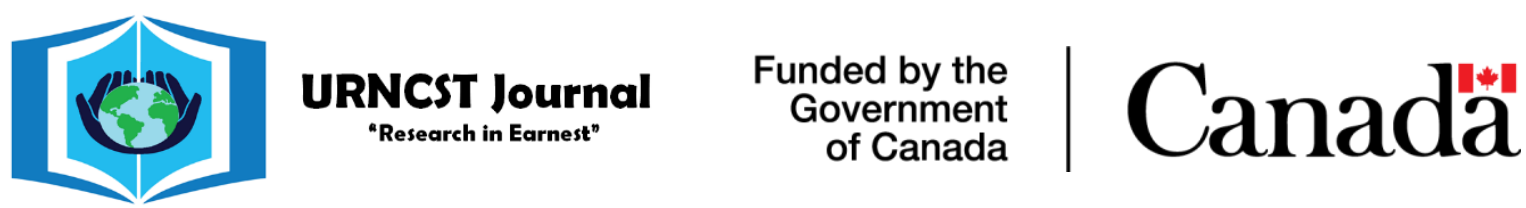

Do you research in earnest? Submit your next undergraduate research article to the URNCST Journal!

| Open Access | Peer-Reviewed | Rapid Turnaround Time | International |

| Broad and Multidisciplinary | Indexed | Innovative | Social Media Promoted |

Pre-submission inquiries? Send us an email at info@ urncst.com | Facebook, Twitter and LinkedIn: @ URNCST

Submit YOUR manuscript today at https://www.urncst.com! 